\title{
Competencies of General Care Nurses in Primary Care: from Understanding to Implementation
}

\author{
Competências do Enfermeiro de Cuidados Gerais em Cuidados de Saúde Primários: \\ da Compreensão à Concretização \\ Competencias del Enfermero de Cuidados Generales en la Atención Primaria de Salud: \\ de la Comprensión a la Aplicación
}

Virgínia Maria Sousa Guedes*; Maria Henriqueta Silva Figueiredo**; João Luís Alves Apóstolo***

\begin{abstract}
Background: The process of developing nursing competencies is influenced by several factors. The framework of competencies for general care nurses includes 96 nursing competencies related to professional, ethical and legal practice, care provision and management, and professional development.

Objectives: To describe which are the most and least understood and implemented competencies by general care nurses in primary health care.

Methodology: A quantitative and descriptive study was conducted on a sample of 90 general care nurses in primary health care, using a questionnaire with a competency scale.

Results: A significant and positive inter-variable correlation was found. The professional, ethical and legal practice had higher mean levels of understanding and implementation; care provision and management had lower mean levels on both variables. The competencies were more understood than implemented.

Conclusion: Understanding competencies is an important factor for their implementation. However, this was not the only factor that influenced the results, because the correlation between the 2 variables is not perfect.
\end{abstract}

Keywords: primary health care; skills; nursing care

\section{Resumo}

Enquadramento: O desenvolvimento de competências em enfermagem é um processo influenciado por vários fatores. $\mathrm{O}$ referencial de competências do enfermeiro de cuidados gerais reúne 96 competências da prática profissional ética e legal, prestação e gestão dos cuidados e desenvolvimento profissional. Objetivos: Descrever quais as competências mais e menos compreendidas e mais e menos concretizadas pelo enfermeiro de cuidados gerais em cuidados de saúde primários.

Metodologia: Estudo quantitativo, descritivo, com uma amostra de 90 enfermeiros de cuidados gerais de cuidados de saúde primários, com aplicação de questionário com uma escala de competências. Resultados: Correlação positiva significativa entre as variáveis. A prática profissional, ética e legal foi o domínio que obteve maiores níveis médios de compreensão e concretização; a prestação e gestão dos cuidados obteve menores médias nas duas variáveis. As competências foram mais compreendidas do que concretizadas. Conclusão: A compreensão das competências é um fator importante na sua concretização. Este não foi o único fator que influenciou os resultados, dado que a correlação entre as 2 variáveis não é perfeita.

Palavras-chave: cuidados de saúde primários; competências; cuidados de enfermagem

\footnotetext{
* MSc., RN, Aces Tâmega I - Baixo Tâmega, ARS Norte, 4600-093, Amarante, Portugal [guedes.vir@ gmail.com]. Contribution to the article: Literature search, experimentation work, data collection, statistical treatment and evaluation, data analysis and discussion, article writing. Address for correspondence: Rua Vista-Alegre n. ${ }^{\circ} 1165$, Alpendorada e Matos, 4575-063 Marco de Canaveses, correspon
Portugal.

** Ph.D., Family Health Nursing, Coordinating Professor, Nursing School of Porto, 4200-072 Porto, Portugal [henriqueta@esenf.pt]. Contribution to the article: Experimentation work, data collection, statistical treatment and evaluation, data analysis and discussion.

*** Ph.D., Elderly Nursing, Coordinating Professor, Nursing School of Coimbra,3046-851, Coimbra, Portugal [apostolo@esenfc.pt].Contribution to the article: Experimentation work, data collection, statistical treatment and evaluation, data analysis and discussion.
}

\section{Resumen}

Marco contextual: El desarrollo de competencias en enfermería es un proceso influido por varios factores. El marco de competencias del enfermero de cuidados generales reúne 96 competencias de la práctica profesional, ética y legal, prestación y gestión de los cuidados y desarrollo profesional. Objetivos: Describir cuáles son las competencias más y menos comprendidas, así como más y menos aplicadas por el enfermero de cuidados generales en la atención primaria de salud.

Metodología: Estudio cuantitativo y descriptivo sobre una muestra de 90 enfermeros de cuidados generales que trabajan en atención primaria de salud mediante un cuestionario con una escala de competencias.

Resultados: Correlación positiva significativa entre las variables. La práctica profesional, ética y legal fue el dominio con niveles medios más elevados de comprensión y aplicación; la prestación y gestión de los cuidados obtuvo medias más bajas en ambas variables. Las competencias fueron más comprendidas que aplicadas.

Conclusión: La comprensión de las competencias es un factor importante para su aplicación. Sin embargo, este no fue el único factor que influyó en los resultados, ya que la correlación entre las 2 variables no es perfecta.

Palabras clave: atención primaria de salud; competencia; atención de enfermería

Received for publication: 10.04 .15

Accepted for publication: 04.02.16 


\section{Introduction}

Primary health care (PHC) can be defined as a set of activities, a level of care, an organizational strategy of health services or a philosophy of health care systems (Biscaia et al., 2008). The first definition of PHC can be found in the Declaration of Alma-Ata (Organização Mundial de Saúde [OMS], 1978), despite the fact that this type of care was already being provided long before this date.

In Portugal, the recorded history of $\mathrm{PHC}$ dates back to the creation of the first health care centers (Decree-Law no. 413/71 of 27 September). Nowadays, the organic structure of PHC is sustained by Decree-Law no. 28/2008, which established the clusters of health care centers (Agrupamentos de Centros de Saúde ACES).

The professional practice of the nurse in PHC allows for a close contact with the community. Thus, the development of competencies in this context is very important to achieve positive health outcomes with an impact on the determinants for social development and policies to achieve change (OMS, 2013).

According to Benner (2001), there are five stages of skills acquisition in nursing, from novice to expert. The framework of competencies of the general care nurse (Ordem dos Enfermeiros [OE], 2003) was also created based on Benner's model (2001), which divided a total of 96 competencies into three domains: professional, ethical and legal practice; care provision and management; and professional development. This document was recently redesigned, combining the competencies previously defined in a structure that is more appropriate to the certification process (Regulamento n. ${ }^{\circ}$ 190/2015 de 23 de abril).

Based on the framework of competencies of the general care nurse (OE, 2003), we aim to describe which are the most and least understood and implemented competencies by general care nurses in PHC.

\section{Background}

\section{Primary Health Care}

PHC is an essential health care based on scientifically sound methods and technologies made universally available to individuals, families and communities, close to the contexts where people live, work or study (OMS,
1978). They aim at preventing the onset of diseases through health promotion and disease protection activities (primary prevention), early detecting the disease and dealing with it promptly to revert, heal, reduce or treat its severity (secondary prevention), and preventing its progression or maintaining the highest quality of life when the process is irreversible (tertiary prevention; Stanhope \& Lancaster, 1999). PHC can also encompass the identification of individuals at risk of excessive treatment, with a view to protecting them against inappropriate medical interventions and suggesting ethically acceptable alternatives (quaternary prevention; Norman \& Tesser, 2009).

In Portugal, PHC has come a long way, from the creation of the first-generation health care centers until today, with the milestone of Decree-Law no. 28/2008 that created the ACES, which consist of one or more health care centers with the mission to provide PHC to a particular geographical area. The ACES are composed of several functional units: family health care unit (unidade de saúde familiar - USF), personalized health care unit (unidade de cuidados de saúde personalizados - UCSP), community care unit (unidade de cuidados na comunidade - UCC), public health unit (unidade de saúde pública - USP), and shared assistance resources unit (unidade de recursos assistenciais partilhados - URAP).

The Declaration of Munich (OMS, 2000) proposed an approach to nursing care based on family-centered programs and services. This declaration was signed in Portugal in the conference A Cada Familia o Seu Enfermeiro (A Nurse for Each Family), which debated experiences of care based on the family nurse (OE, 2002, cited by Figueiredo, 2009). If the family system is seen as one of the areas of intervention of health promotion strategies, this can be translated into a greater effectiveness of strategic planning and problem solving (OE, 2002, cited by Figueiredo, 2009). We should consider the complexity and properties of "wholeness, equifinality and self-organization" (Figueiredo, 2012, p. XI) that characterize the family. The regulation of the USFs sustains the model of the family nurse as an organizational concept (Decreto-Lei n. ${ }^{0}$ 28/2008 de 28 de fevereiro). The UCCs focus on individuals, families and vulnerable groups (DecretoLei n. ${ }^{\circ}$ 28/2008, 28 de fevereiro), considering the community itself as unit of context.

The Health 2020 conceptual framework currently serves as reference to European health policies and 
its key objective for 2020 is to improve the health and well-being of the population, as well as to reduce health inequalities through the following strategic priorities: investing in health through a life-course approach and empowering people; fighting against communicable and non-communicable diseases; strengthening people-centered health care systems and public health capacity; and creating resilient communities and supportive environments (OMS, 2013, cited by DGS, 2015).

According to the WHO, nurses play an increasingly important role in society and in the efforts to face the challenges in $\mathrm{PHC}$, so as to ensure the continuity of care and the fundamental rights of individuals. Because they have close contact with the populations, nurses should possess primary health care competencies so that they can use every opportunity to positively influence health outcomes, their social determinants and the policies necessary to achieve change (OMS, 2013).

\section{Competencies of the General care Nurse}

According to Le Boterf (2000), competency is a process which results in knowing how to manage a complex professional situation, influenced by factors relating to the subject's biography, professional situation and training/education. Several contents may be dissociated from competency: knowledge, technical skills and behavioral skills (Dias, 2006). Theoretical, experiential and procedural knowledge is acquired essentially through initial and lifelong training and may be verbally expressed by the individual; the experimental, operational, social, relational and cognitive knowledge is acquired through professional and social experiences, formal education, lifelong training and capacity for analysis, being expressed through behavioral dynamics (Le Boterf, 2000).

The Dreyfus' model describes the acquisition and development of skills in five stages: novice, advanced beginner, competent, proficient, and expert (Dreyfus, 1981, cited by Rauner, 2007). The model was applied to the nursing profession by Patricia Benner (2001), who described the process of skills acquisition and development in five stages. Therefore, the competent nurse has been working in the same job for at least 2 years, has the capacity to perceive his/her actions in terms of long-term goals, is able to establish a plan based on a conscious and abstract analysis, and is able to cope with many unforeseen events (Benner, 2001). In Portugal, the competencies of the general care nurse were initially described in the framework of competencies of the general care nurse, which was published by the OE in 2003. This document includes 96 competencies that "refer to a level of professional performance demonstrating the effective application of knowledge and skill, including judgement" (OE, 2003, p. 16). These competencies are divided into three areas: professional, ethical and legal practice; care provision and management; and professional development. The document was recently redesigned and approved by the Directive Council of the OE, resulting in a new regulation that keeps all the competencies included in the previous framework, but adds the concept of Criterion of Competence (Critério de Competência), as well as the concepts of Domain of Competence (Domínio de Competência) and Standard or Description of Competence (Norma ou Descritivo de Competência), in order to facilitate the process of certification (Regulamento $\mathrm{n.}^{\mathrm{O}}$ 190/2015 de 23 de abril).

Considering that nurses represent $60 \%$ to $80 \%$ of the total workforce in a health care system, while providing $90 \%$ of all health care services (OMS, 2008, cited by the International Council of Nurses [ICN], 2012), it is essential that their skills and competencies are recognized and optimized in the PHC reform (ICN, 2012). Therefore, with this study, we aimed to identify the perception of general care nurses in PHC concerning the most and least understood and implemented practices, so as to be able to recommend improvements to care.

\section{Research Questions}

What are the most and least understood competencies by general care nurses in primary health care? What are the most and least implemented competencies by general care nurses in primary health care?

\section{Methodology}

A quantitative, descriptive study was developed with a sample of 90 general care nurses working in an ACES of the district of Porto. The inclusion criterion was having at least 2 years of professional experience 
(Benner, 2001). Nurses with a specialization degree were not included in the sample.

We had a participation rate of $51 \%$, corresponding to a total of 46 nurses: 93\% were female and 7\% were male. In this sample, $63 \%$ of the nurses worked in UCSPs, 30\% in USFs, and 7\% in UCCs. The mean age of the sample was 32 years. The mean total length of service was 9.59 years, whereas the mean total length of service in PHC was 7.13 years.

Before the application of the data collection tool, formal authorization was requested to, and granted by, the Ethics Committee for Health of the Regional Health Administration of the North. Each questionnaire also included a letter explaining the study for the participants' informed consent.

The variables defined for this study were the concepts of understanding (assigning a meaning) and implementation (the actual practice) of the competencies of the general care nurse.

The questionnaire was composed of questions for demographic characterization and the Scale of General Care Nurse Competencies (Escala de Competências do Enfermeiro de Cuidados Gerais - ECECG). This is a Likert-type scale ranging from 1 to 3 , in which 1 corresponds to not at all and 3 corresponds to completely. This scale was applied to each competency of the general care nurse (OE, 2003), in the variable I understand and in the variable I implement. The pretest was applied to 10 nurses, who confirmed that the instrument was easily understood and applied. The questionnaires were distributed and collected between September 2010 and June 2011.

The ECECG showed a good internal consistency, with Cronbach's alpha values ranging between 0.831 and 0.965 in the three domains, and 0.971 in total. Data were analyzed using the software Statistical Package for Social Sciences (SPSS), version 16.0, for a descriptive statistical analysis.

\section{Results}

Through the statistical analysis of the variable $I$ understand, we observed that the answers ranged between the minimum value of 1 and the maximum value of 3 . The means ranged between 2.29 and 2.90 , and the standard deviation ranged between 0.158 and 0.273 . The most understood competencies were no. 34 "Sees the individual, the family and the community from a holistic perspective that takes into account the multiple health determinants" (mean=2.98), no. 49 - "Establishes care priorities, whenever possible, in collaboration with patients and/or caregivers" (mean=2.97), and no. 63 - "Ensures that the information provided to the patient and/or caregivers is adequate and clear" (mean $=2.97$ ). All of these competencies belong to the domain related to care provision and management.

The least understood competencies were no. 31 "Demonstrates understanding of the emergency plans for a disaster situation" (mean=2.29), no. 81 - "Uses a series of support strategies when supervising aspects of care delegated to another nurse" (mean $=2.36$ ), no. 27 - "Demonstrates understanding of the legal processes associated with health care" (mean $=2.37$ ), and no. 39 - "Demonstrates understanding of the traditional practices of the health belief systems of individuals, families and communities" (mean $=2.37$ ). All of these competencies belong to the domain related to care provision and management.

In the analysis of the variable I implement, we found that the answers ranged between the minimum value of 1 and the maximum value of 3 . The means varied between 2.02 and 2.89, and the standard deviation ranged between 0.315 and 0.821 .

The most implemented competencies were no. 8 "Respects the patients' right of access to information" (mean $=2.89)$, no. 9 - "Ensures the confidentiality and safety of written and oral information acquired as a professional" (mean $=2.89$ ), and no. 17 - "Intervenes in accordance with the applicable legislation" (mean $=2.89$ ).

The least implemented competencies were no. 90 "Participates in programs on quality improvement and quality assurance procedures" (mean $=2.02$ ), no. 57 - "Provides an effective response in emergency and disaster situations" (mean=2.07), no. 31 "Demonstrates understanding of the emergency plans for a disaster situation" (mean $=2.15$ ), and no. 81 - "Uses a series of support strategies when supervising aspects of care delegated to another nurse" (mean $=2.15$ ).

As Table 1 shows, the results concerning the mean of each domain show that the professional, ethical and legal practice had the highest levels of understanding and implementation of the respective competencies. Care provision and management had the lowest levels of understanding and implementation. 
Table 1

Mean, standard deviation and Spearman's coefficient of the variables in each domain of competencies

\begin{tabular}{llcccc}
\hline Domain and Variable & & No. & Mean & Standard deviation & Spearman's coefficient $(r)$ \\
\hline \multirow{2}{*}{$\begin{array}{l}\text { A-Professional, ethical and legal } \\
\text { practice }\end{array}$} & I understand & 46 & 2.87 & 0.170 & \multirow{2}{*}{0.615} \\
\cline { 2 - 5 } \multirow{2}{*}{ B-Care provision and management } & I implement & 46 & 2.72 & 0.248 & \multirow{2}{*}{0.696} \\
\cline { 2 - 5 } C-Professional development & I implement & 46 & 2.55 & 0.295 & \multirow{2}{*}{0.452} \\
\cline { 2 - 5 } & I understand & 46 & 2.83 & 0.278 & 0.330 \\
\hline
\end{tabular}

Through the calculation of Spearman's coefficient, we found a positive correlation between the variables $I$ understand and I implement, which varied between 0.884 and 0.300 , being higher in competency no. 17 - "Intervenes in accordance with the applicable legislation" and lower in competency no. 81 - "Uses a series of support strategies when supervising aspects of care delegated to another nurse".

\section{Discussion}

Taking into account the variation of the ECECG (1 to 3 ), we consider that the results found in the means of both variables were positive because they were always higher than 2. Considering that understanding is a theoretical knowledge acquired in formal training and expressed in the declarative mode (Le Boterf, 2000), and that the variable I understand aims at measuring the level of understanding of the competencies in a specific statement, the results concerning this variable may be related to the nurses' theoretical knowledge about its contents. In this way, the results concerning this variable may indicate higher levels of theoretical knowledge concerning holistic concepts, definition of priorities and processing of clear information.

In general, the results concerning the variable $I$ understand are always higher than the results concerning the variable I implement. The positive correlation between both variables calls our attention to the influence of understanding on implementation. The results concerning the most understood competencies (no. 34 - "Sees the individual, the family and the community from a holistic perspective that takes into account the multiple health determinants"; no. 49 - "Establishes care priorities, whenever possible, in collaboration with patients and/or caregivers"; and no. 63 - "Ensures that the information provided to the patient and/or caregivers is adequate and clear", all belonging to the domain of care provision and management) are partially in line with the study of Mendonça (2009), in which competency no. 49 "Establishes care priorities, whenever possible, in collaboration with patients and/or caregivers" is one of the most perceived competencies by the sampled nurses.

In turn, the least understood competencies (no. 31 - "Demonstrates understanding of the emergency plans for a disaster situation"; no. 81 - "Uses a series of support strategies when supervising aspects of care delegated to another nurse"; no. 27 - "Demonstrates understanding of the legal processes associated with health care"; and no. 39 - "Demonstrates understanding of the traditional practices of the health belief systems of individuals, families and communities") can suggest a lower level of theoretical knowledge of its contents when compared to the others.

The most implemented competencies belong to the domain of professional, ethical and legal practice: no. 8 - "Respects the patients' right of access to information"; no. 9 - "Ensures the confidentiality and safety of written and oral information acquired as a professional"; and no. 17 - "Intervenes in accordance with the applicable legislation". It should be noted that competency no. 17 had the highest correlation among the variables, which means that it was the competency whose understanding most influenced its implementation. This result certainly reflects the theoretical knowledge of the deontological basis that sustains the nursing profession and its effective implementation.

The results concerning the least implemented competencies (no. 90 - "Participates in programs on quality improvement and quality assurance procedures", no. 57 - "Provides an effective response 
in emergency and disaster situations", no. 31 "Demonstrates understanding of the emergency plans for a disaster situation", and no. 81 - "Uses a series of support strategies when supervising aspects of care delegated to another nurse") highlight the existence of other factors influencing the implementation of competencies beyond the theoretical knowledge. These factors may be related to the subject's biography or professional situation (Le Boterf, 2000). This fact is even more evident in competency no. 81, since it shows the lowest inter-variable correlation.

After analyzing the results on the domains which represent groups of competencies, we concluded that the domain of professional, ethical and legal practice has the highest mean level of understanding and implementation. This result is in line with a study carried out to assess the levels of self-efficacy in the competencies of general care nurses (in a sample of final-year students), which reported higher levels of self-efficacy related to the ethical and moral practice (Oliveira, 2010). Care provision and management had the lowest mean level of understanding and implementation. This domain includes the largest number of competencies and is composed of the following subdomains: key principles of care provision and management, care provision (health promotion, data collection, planning, implementation, evaluation, and communication and interpersonal relationship) and care management (safe environment, multidisciplinary health care, and delegation and supervision).

The main limitation of this study is its small sample size, which was initially composed of 90 nurses and later reduced to 46 participants. We believe that a larger sample could produce more meaningful results.

\section{Conclusion}

We conclude that the most understood competencies may reflect a higher theoretical knowledge of their contents. The least understood competencies may indicate less theoretical knowledge of the contents.

The most implemented competencies belong to the domain of professional, legal and ethical practice, which means that nurses act based on the ethical principles that underpin the profession. The results on the least implemented competencies indicate a lower effective practice of activities related to the continuous quality improvement and quality assurance procedures, intervention in situations of emergency and disaster, and understanding of emergency plans for a disaster situation.

In general, competencies are significantly less implemented than understood. The positive inter-variable correlation and the higher mean values of the variable I understand, when compared to the mean values of the variable I implement, indicate that, besides the levels of theoretical knowledge on the contents, other factors have influenced the performance of the competencies of general care nurses in PHC.

The results of this study may suggest the adoption of organizational strategies to optimize the development of the least implemented competencies by the general care nurse in $\mathrm{PHC}$, taking into account the factors influencing it. Similarly, the results concerning the least understood competencies may indicate the need for training on their contents.

The adoption of strategies aimed at improving the development of competencies will have a significant impact on the continuous improvement of nursing care.

\section{References}

Biscaia, A., Martins, J. N., Ferrinho, P., Gonçalves, I., Antunes, A. R. \& Carreira, M. (2008). Cuidados de Saúde Primários em Portugal: Reformar para novos sucessos ( $2^{\mathrm{a}}$ ed.). Lisboa, Portugal: Padrões Culturais Editora.

Benner, P. (2001). De Iniciado a Perito. Coimbra, Portugal: Quarteto.

Decreto-Lei n. ${ }^{0}$ 413/71 de 27 de setembro. Diário da República $n .^{\circ} 228$ - I Série. Ministério da Saúde e Assistência. Lisboa, Portugal.

Decreto-Lei n. ${ }^{\circ}$ 28/2008 de 22 fevereiro. Diário da República n. 38 - I Série. Conselho de Ministros. Lisboa, Portugal.

Dias, F. (2006). Construção e validação de um inventário de competências: Contributos para a definição de um perfil de competências do enfermeiro com grau de licenciado. Loures, Portugal: Lusociência.

Figueiredo, M. H. (2009). Enfermagem de família: Um contexto do cuida (PhD Thesis). Instituto de Ciências Biomédicas Abel Salazar, Porto, Portugal.

Figueiredo, M. H. (2012). Modelo dinâmico de avaliação e intervenção familiar: Uma abordagem colaborativa em Enfermagem de Família. Loures, Portugal: Lusociência. 
International Council of Nurses (2012). Reforming primary bealth care: A nursing perspective. Geneva, Switzerland : Author.

Le Boterf, G. (2000). Compétence et navigation professionelle. Paris, France: Editions d' Organization.

Mendonça, S. S. (2009). Competências profissionais dos enfermeiros: A excelência do cuidar. Lisboa, Portugal: Editorial Novembro.

Norman, A. R. \& Tesser C. D. (2009). Prevenção quaternária na atenção primária à saúde: Uma necessidade do Sistema Único de Saúde. Cadernos de Saúde Pública, 25(9), 20122020.

Oliveira, P. C. (2010). Auto-eficácia específica nas competências do enfermeiro de cuidados gerais: Percepção dos estudantes finalistas do curso de licenciatura em enfermagem (Masters dissertation). Universidade Portucalense Infante D. Henrique. Porto, Portugal.

Ordem dos Enfermeiros. (2003). Competências do enfermeiro de cuidados gerais. Lisboa, Portugal: Autor.
Organização Mundial de Saúde (1978, setembro). Declaração de Alma-Ata. Conferência Internacional sobre Cuidados Primários de Saúde, Alma-Ata, 6-12 de Setembro. Alma-Ata, URSS: Autor.

Organização Mundial de Saúde (2000, junho). A Enfermagem de saúde familiar, contexto, quadro conceptual e currículo. $2^{\text {a }}$ Conferência da OMS para a Enfermagem Obstétrica. Munique, Alemanha: Autor.

Rauner, F. (2007). Conhecimento prático e competência profissional. Revista Europeia de Formação Profissional, $40(1), 57-71$.

Regulamento n. ${ }^{\circ}$ 190/2015 de 23 de abril. Diário da República II série n. ${ }^{\circ} 79$ - II série. Ordem dos Enfermeiros. Lisboa, Portugal.

Stanhope, M. \& Lancaster, J. (1999). Enfermagem Comunitária: Promoção da saúde de Grupos, Famílias e Indivíduos (4a ed.). Lisboa, Portugal: Lusociência. 
